\title{
Penerapan Agile Scrum Pada Pengembangan Aplikasi Bimbingan Daring Skripsi Mahasiswa
}

\author{
${ }^{1}$ Meta Amalya Dewi, ${ }^{2}$ Rafi Irham \\ ${ }^{1,2}$ Sistem Informasi Tanri Abeng University, \\ Jl. Swadarma Raya No. 58 Ulujami Pesanggrahan Jakarta Selatan \\ 1meta.amalya@tau.ac.id, ${ }^{2}$ rafi.irham@student.tau.ac.id \\ Diterima : 23 Februari 2021 \\ Disetujui : 28 Maret 2021
}

\begin{abstract}
Pada Perguruan Tinggi, skripsi menjadi persyaratan kelulusan yang harus diselesaikan oleh setiap mahasiswa melalui proses pembimbingan dengan dosen pembimbing, namun semenjak akhir Maret 2020 mahasiswa tidak dapat lagi bertemu dengan dosen pembimbing secara langsung karena semua aktivitas kampus dilakukan secara daring sebagai bagian dari pencegahan penyebarluasan virus Covid-19. Aplikasi bimbingan daring skripsi mahasiswa ini dikembangkan sebagai media interaksi antara mahasiswa dan dosen pembimbing dengan menyediakan fasilitas untuk unduh berkas, catatan perbaikan digital dan informasi capaian penyelesaian mahasiswa. Agile Scrum digunakan sebagai metode pengembangan yang menghasilkan 4 sprint dengan durasi 336 jam atau sama dengan 9 minggu dimana dalam 1 minggu 8 jam perhari selama 5 hari kerja. Tahapannya dimulai dari penentuan product backlog berdasarkan user stories, sprint, scrum meeting dan demo untuk mendapatkan feedback yang cepat di hadapan klien. Aplikasi ini sebagai solusi sehingga pelaksanaan prose pembimbingan tetap dapat dilakukan secara optimal.
\end{abstract}

Key words : Sprint, bimbingan, skripsi, daring.

\section{PENDAHULUAN}

Skripsi menjadi persyaratan kelulusan seorang mahasiswa dengan menghasilkan karya ilmiah berdasarkan hasil penelitian yang dilakukan melalui proses analisis data baik primer maupun sekunder [1]. Hal ini tertuang pada Undang-Undang Nomor 12 Tahun 2012 mengenai Pendidikan Tinggi yang berisi bahwa pendidikan, penelitian dan pengabdian kepada masyarakat wajib untuk diselenggarakan oleh Pendidikan Tinggi [2] dan pelaksanaan skripsi mahasiswa merupakan bagian dari kegiatan Tridarma bidang penelitian. Proses penyelesaian skripsi mahasiswa didampingi oleh dosen pembimbing yang bertanggung jawab atas apa yang ditulis dan dihasilkan mahasiswa bimbingannya [3].

Mulai Akhir Maret 2020 proses bimbingan tidak dapat berjalan secara tatap muka sebagaimana yang tercantum dalam buku pedoman karena pandemi Covid-19 sebagaimana Surat Edaran Rektor Universitas Tanri Abeng No 14/03/SATGASCOVID/TAU/IX/2020 tentang pencegahan dan Pengendalian Covid-19 di lingkungan kampus [4] yang mengacu pada edaran Kementrian Pendidikan dan Kebudayaan Nomor: 36962/MPK.A/HK/2020 tanggal 17 Maret 2020 [5] menjadi sebab pelaksanaan kegiatan perkuliahan termasuk proses bimbingan dilakukan secara daring dan merupakan kebijakan khusus untuk peserta didik dari taman kanak-kanak (TK) sampai Pendidikan Tinggi sehingga interaksi antara pendidik (guru dan dosen) dengan peserta didik dilakukan melalui teknologi [6].

Pandemi Covid-19 menuntut Perguruan Tinggi untuk mampu beradaptasi dengan kondisi yang ada [7]. Untuk mengatasi permasalahan pembimbingan dan tetap memberikan layanan serta dukungan proses bimbingan secara optimal, maka penelitian ini dilaksanakan untuk mengembangankan aplikasi sistem informasi bimbingan daring skripsi mahasiswa dengan nama Online Thesis Concultation AplicationTanri Abeng University (OTCA-TAU) yang memudahkan interaksi antara dosen pembimbing dengan mahasiswa dan menyimpan hasil tinjauan serta catatan revisi secara digital. 


\section{Metode PENELITIAN}

Pengembangan OCTA-TAU dilakukan melalui beberapa tahapan kegiatan penelitian secara berurutan sebagai berikut :

\section{A. Pengumpulan Data}

Pengumpulan data dilaksanakan menggunakan tehnik observasi dan wawancara. Observasi dilakukan di Tanri Abeng University yang memiliki 2 fakultas dan 10 program studi, sementara wawancara dilakukan dengan mengajukan sejumlah pertanyaan kepada Manager Akademik terkait dengan prosedur dan proses bimbingan skripsi di lingkungan kampus, juga kepada calon pengguna atau end user yaitu mahasiswa dan dosen.

\section{B. Analisis Sistem Berjalan}

Data yang didapatkan pada tahap sebelumnya dipelajari dan dievaluasi dari berbagai permasalahan yang ada untuk dihasilkan analisis kebutuhan untuk sistem yang baru dan dimodelkan dengan Unified Modelling Language (UML) yang sudah menjadi bahasa standar pemodelan rekayasa perangkat lunak 'berorientasi objek' untuk menyederhanakan berbagai masalah kompleks menjadi mudah dipahami [8] menggunakan diagram usecase dan activity.

\section{Pengembangan Sistem}

Metode Agile Scrum Develompent digunakan dalam pengembangan OTCA-TAU ini karena dinilai memiliki kelebihan dibanding metode pengembangan lainnya, yaitu cukup dilakukan dengan tim yang kecil dapat dihasilkan aplikasi yang sesuai lingkungan dan mudah beradaptasi terhadap perubahan selama proses pengembangan [9]. Selain itu dihasilkan penggunaan waktu pengembangan software yang optimal [10].

Tahapan Agile Scrum [11] dimulai dari penentuan tim, penentuan product backlog, tahapan sprint seperti visualisasi di bawah ini :

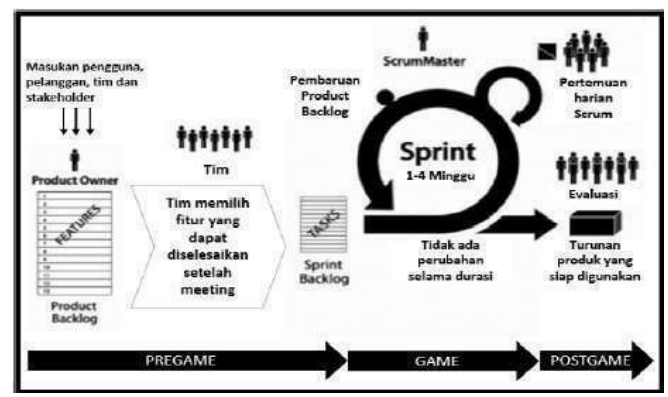

Gambar 1 Tahapan Pengembangan Scrum [11]

1. Backlog

Backlog merupakan daftar kebutuhan atau fitur yang memiliki business value bagi klien dan harus diselesaikan selama pengembangan sistem.

2. Sprints

Sprints merupakan bagian pekerjaan yang dibutuhkan untuk dipenuhi sesuai waktu yang dijadwalkan dalam time-box dan telah ditetapkan dalam backlog.

3. Scrum Meetings

Scrum meetings dilaksanakan sebagai aktivitas pertemuan terjadwal selama sprint berlangsung membahas pekerjaan yang telah dilakukan, permasalahan yang dihadapi, serta target penyelesaian sebagai bahan pembahasan pertemuan berikutnya.

\section{Demo}

Presentasi Demo aplikasi di hadapan klien untuk dievaluasi dalam rangka peningkatan rekayasa perangkat lunak setelah penulisan coding dilakukan menggunakan bahasa pemrograman PHP, dreamweaver, MySQL dan Xampp

\section{HASIL DAN PEMBAHASAN}

\section{A. Pengumpulan Data}

Kegiatan pengumpulan data dilaksanakan melalui pengamatan secara langsung di Tanri Abeng University dan dilakukan wawancara kepada tiga pihak yang akan dihasilkan user stories (penjelasan pada sub bab C.1) dari calon pengguna atau end user sebagai berikut :

\begin{tabular}{|l|l|l|l|}
\hline \multicolumn{4}{|c|}{ Tabel 1. Responden sebagai calon pengguna } \\
\hline No & Responden & Jumlah & $\begin{array}{l}\text { User } \\
\text { Level }\end{array}$ \\
\hline $\mathbf{1}$ & $\begin{array}{l}\text { Staff dan } \\
\text { Kabiro Akademik }\end{array}$ & 2 & Admin \\
\hline $\mathbf{2}$ & Dosen & $\begin{array}{l}5 \text { dosen } \\
\text { mewakili 10 } \\
\text { prodi }\end{array}$ & User \\
\hline $\mathbf{3}$ & Mahasiswa & $\begin{array}{l}10 \text { mahasiswa } \\
\text { pada } 10 \text { prodi }\end{array}$ & User \\
\hline
\end{tabular}

a) Analisis Sistem Berjalan

Setelah data didapatkan melalui observasi dan wawancara terkait proses bimbingan pada sistem berjalan kemudian dianalisis dan dimodelkan menggunakan diagram activity yang seperti pada 
gambar 2 yang diawali penyerahan berkas dari mahasiswa untuk diperiksa dosen pembimbing selanjutnya dosen pembimbing memberikan penjelasan dan memberikan catatan perbaikan di kartu bimbingan mahasiswa sebagai petunjuk mahasiswa melakukan perbaikan terhadap penulisannya.

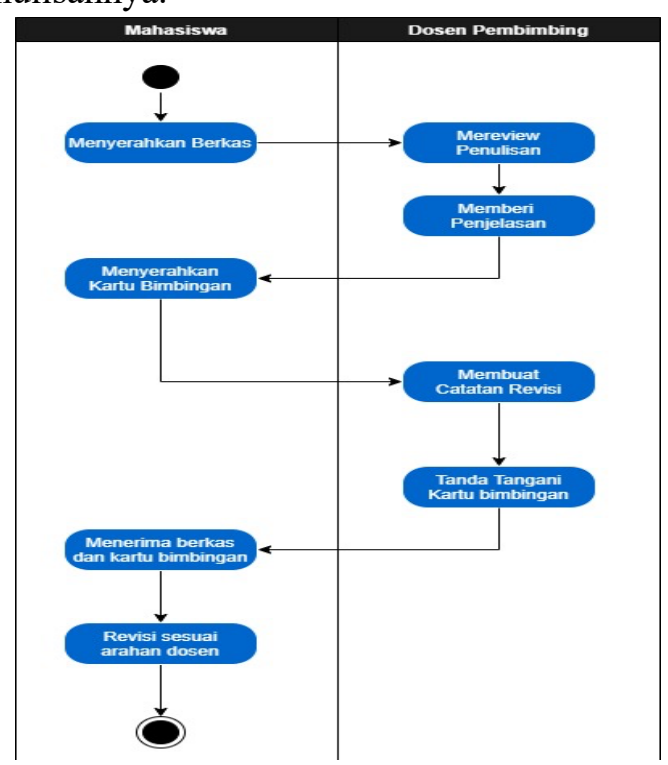

Gambar 2. Diagram Activity Sistem Berjalan

Berdasarkan hasil analisis yang sudah di dapatkan, maka dibuat pengembangan aplikasi berbasis web sebagai media interaksi antara mahasiswa dengan dosen pembimbing yang melaksanakan bimbingan secara daring dan dimodelkan seperti pada gambar 3 dimana terdapat 3 aktor yaitu admin sebagai pengelola data, berita dan pengguna, mahasiswa yang dapat upload berkas, melihat catatan perbaikan dan actor dosen pembimbing yang melakukan pemeriksaan berkas setelah diunduh, membuat catatan perbaikan dan dapat melakukan diskusi online dengan mahasiswa atau menyelenggarakan pertemuan daring dengan Google meet jika diperlukan.

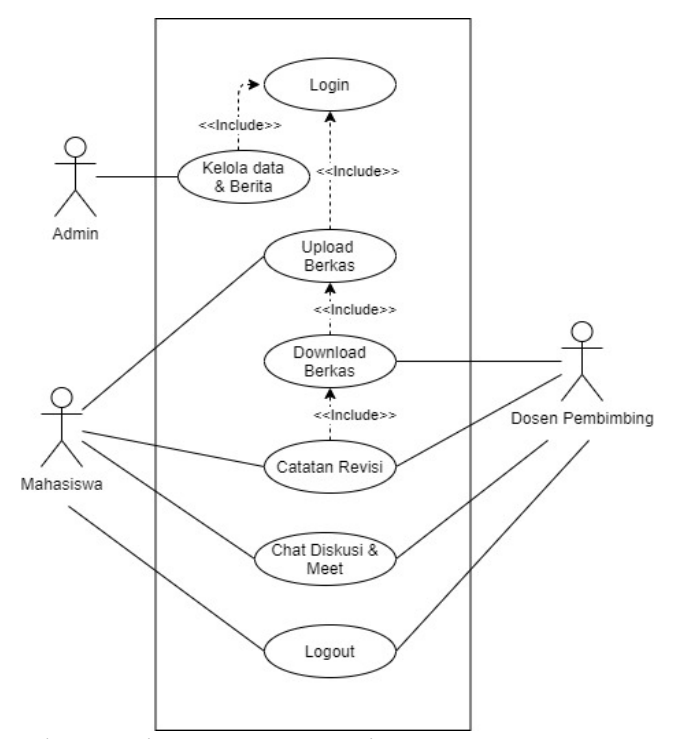

Gambar 3. Diagram Usecase Sistem Rancangan OCTATAU

\section{b) Pengembangan Sistem}

\section{User Stories}

Pelaksanaan pengembangan produk aplikasi OCTA-TAU dilakukan dengan analisis yang dibutuhkan sistem dari sumber calon pengguna sistem atau end user. User stories diperoleh pada tahap pengumpulan data melalui wawancara yang sudah dilakukan, maka dapat disimpulkan kebutuhan pengguna adalah sebagai berikut :

a. Staff Akademik : "Saya ingin aplikasi dapat mengelola data pengguna, dosen dan mahasiswa, submit berita atau informasi serta monitoring bimbingan"

b. Mahasiswa : "Saya ingin aplikasi dapat upload berkas bimbingan yang akan dikoreksi oleh dosen pembimbing, mendapatkan penjelasan secara rinci melalui forum diskusi dan pertemuan online dengan dosen pembimbing"

c. Dosen Pembimbing : "Saya ingin aplikasi dapat menampilkan berkas mahasiswa yang harus direview, memberikan penjelasan melalui chat diskusi dan pertemuan online, serta dapat menuliskan catatan perbaikan yang harus dilakukan mahasiswa"

\section{Product Backlog}

Pada Tahapan ini, kebutuhan pengguna dikelompokkan menjadi daftar fitur yang harus diselesaikan sesuai dengan prioritas dan estimasi waktu yang tersedia. Rincian product backlog dapat dilihat pada table di bawah ini : 
Tabel 2 Product Backlog

\begin{tabular}{|c|c|c|c|}
\hline Backlog & Prioritas & Item & $\begin{array}{l}\text { Estimasi } \\
\text { Waktu } \\
\text { (Jam) }\end{array}$ \\
\hline $\begin{array}{l}\text { Web } \\
\text { back } \\
\text { end }\end{array}$ & Penting & $\begin{array}{l}\text { - Pengelolaan berita } \\
\text { - Pengelolaan data mahasiswa } \\
\text { - Pengelolaan data dosen } \\
\text { - Pengelolaan user } \\
\text { - Monitoring bimbingan }\end{array}$ & $\begin{array}{l}8 \\
16 \\
16 \\
8 \\
25\end{array}$ \\
\hline $\begin{array}{l}\text { Web } \\
\text { Front } \\
\text { end }\end{array}$ & Penting & $\begin{array}{l}\text { - View berita/informasi } \\
\text { - Input \& view jadwal bimbingan } \\
\text { - Submit \& view betkas mahasiswa } \\
\text { - Approval/revisi penulisan } \\
\text { - Input \& view catatan revisi } \\
\text { - Forum diskusi } \\
\text { - Pertemuan online }\end{array}$ & $\begin{array}{l}10 \\
12 \\
16 \\
16 \\
10 \\
23 \\
16\end{array}$ \\
\hline $\begin{array}{l}\text { Student } \\
\text { Interface }\end{array}$ & Penting & $\begin{array}{l}\text { Pengaturan akses mahasiswa } \\
\text { terhadap menu berita dan student }\end{array}$ & 80 \\
\hline $\begin{array}{l}\text { Lecturer } \\
\text { Interface }\end{array}$ & Penting & $\begin{array}{l}\text { Pengaturan akses dosen terhadap } \\
\text { menu berita dan dosen pembimbing }\end{array}$ & 80 \\
\hline
\end{tabular}

\section{Sprint}

Setelah dihasilkan kesepakatan atas product backlog item dan juga telah dipahami oleh tim sehingga dapat dikelompokkan menjadi 4 sprint dengan total durasi yang dibutuhkan adalah sebagai berikut :

Tabel 3. Sprint

\begin{tabular}{|l|l|l|l|}
\hline No & Fitur Backlog & $\begin{array}{l}\text { Urutan } \\
\text { Sprint }\end{array}$ & $\begin{array}{l}\text { Total } \\
\text { Durasi } \\
\text { (jam) }\end{array}$ \\
\hline 1 & Web Back end & Sprint 1 & 73 \\
\hline 2 & Web Front end & Sprint 2 & 103 \\
\hline 3 & $\begin{array}{l}\text { Student } \\
\text { Interface }\end{array}$ & Sprint 3 & 80 \\
\hline 4 & $\begin{array}{l}\text { Lecturer } \\
\text { Inferface }\end{array}$ & Sprint 4 & 80 \\
\hline
\end{tabular}

Pengembangan sistem dilaksanakan selama 9 minggu mulai dari minggu ke 2 bulan Oktober hingga minggu ke 2 bulan Desember 2020 dengan kebutuhan total durasi sebesar 336 jam, dimana dalam 1 hari kerja adalah 8 jam yaitu pukul 08.00 sampai 17.00 (jam istirahat 12.0013.00) dan jumlah hari kerja yaitu 5 hari, Senin hingga Jum'at.

Sprint 1 dilaksanakan 73 jam pada minggu 1 hingga minggu 2, sisa waktu 7 jam digunakan untuk memulai Sprint 2 dilanjut sampai minggu 5 sehingga total durasi adalah 103 jam, sisa waktu pada minggu 5 sebanyak 24 jam digunakan untuk pekerjaan Sprint 3 dengan kebutuhan durasi 80 jam dan selesai pada minggu 7 dengan sisa waktu 24 jam digunakan untuk Sprint 4 dengan kebutuhan durasi 80 jam dan selesai pada minggu 9 yaitu minggu ke 2 bulan Desember 2020

Tabel 4. Timeline Kegiatan Pengembangan Sistem

\begin{tabular}{|l|l|l|l|l|c|}
\hline \multirow{4}{*}{ Month } & $\begin{array}{r}\text { Kegiatan } \\
\text { Durasi } \\
\text { (jam) }\end{array}$ & 1 & 2 & 3 & 4 \\
\hline \multirow{3}{*}{$\begin{array}{l}\text { Okt } \\
2020\end{array}$} & Week 1 & 40 & & & \\
\cline { 2 - 6 } & Week 2 & 33 & 7 & & \\
\cline { 2 - 6 } & Week 3 & & 40 & & \\
\hline \multirow{3}{*}{$\begin{array}{l}\text { Nov } \\
2020\end{array}$} & Week 4 & & 40 & & \\
\cline { 2 - 6 } & Week 5 & & 16 & 24 & \\
\cline { 2 - 6 } & Week 6 & & & 40 & \\
\cline { 2 - 6 } & Week 7 & & & 16 & 24 \\
\hline \multirow{2}{*}{$\begin{array}{l}\text { Des } \\
2020\end{array}$} & Week 8 & & & & 40 \\
\cline { 2 - 6 } & Week 9 & & & & 16 \\
\hline
\end{tabular}

\section{Melakukan Scrum Meeting}

Scrum Meeting merupakan aktivitas penting di dalam Agile Scrum Development, pelaksanaannya harus dijadwalkan secara rutin setiap hari selama sprint berlangsung dengan melaksanakan daily stand up meeting pada pukul 16.00-16.15. Sprint review dilaksanakan H-1 sprint berakhir untuk mengevaluasi dan memastikan penyelesaian sprint dan dilanjutkan sprint retrospective yang dilaksanakan pada hari terakhir masa sprint membahas peningkatan kinerja untuk pelaksanaan sprint berikutnya.

\section{Demo}

Tahap selanjutnya adalah presentasi hasil produk di hadapan klien dan klien dapat secara langsung melakukan evaluasi sehingga didapatkan peningkatan dari hasil rekayasa perangkat lunak. Adapun tampilan dari hasil perancangan aplikasi OCTA-TAU dapat dijelaskan melalui gambar berikut : 


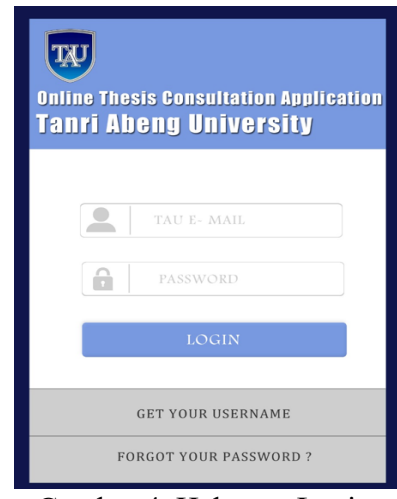

Gambar 4. Halaman Login

Login diisi dengan memasukkan TAUemail sebagai username dan password, jika lupa password dapat klik pada tombol forgot your password maka informasi penggantian akan terkirim melalui email dan jika pengisian login benar maka masuk ke halaman home seperti gambar 5 berikut.

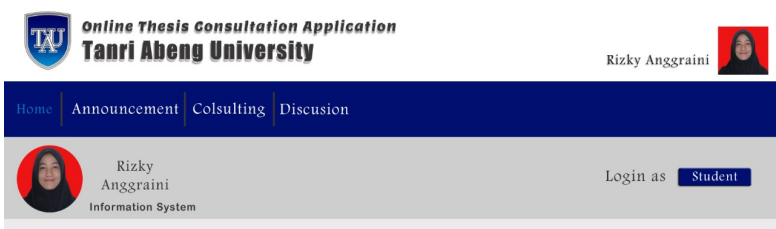

Selamat datang Rizky Anggraini di aplikasi Bimbingan Skripsi Daring (OCTA- TAU) Aplikasi ini sebagai media interaksi antara mahasiswa dan dosen pembimbing selama proses pembimbingan skripsi dilakukan

Progress kamu saat ini adalah :

$10 \%$

Tetap Semangat mengerjakan karena skirpsi yang baik adalah skripsi yang dikerjakan

Gambar 5. Halaman home untuk mahasiswa

Gambar di atas adalah halaman home untuk mahasiswa, pada halaman tersebut terdapat persentase progres skripsinya sebagai informasi capaian dan menjadi dorongan atau semangat untuk meningkatkan progresnya.

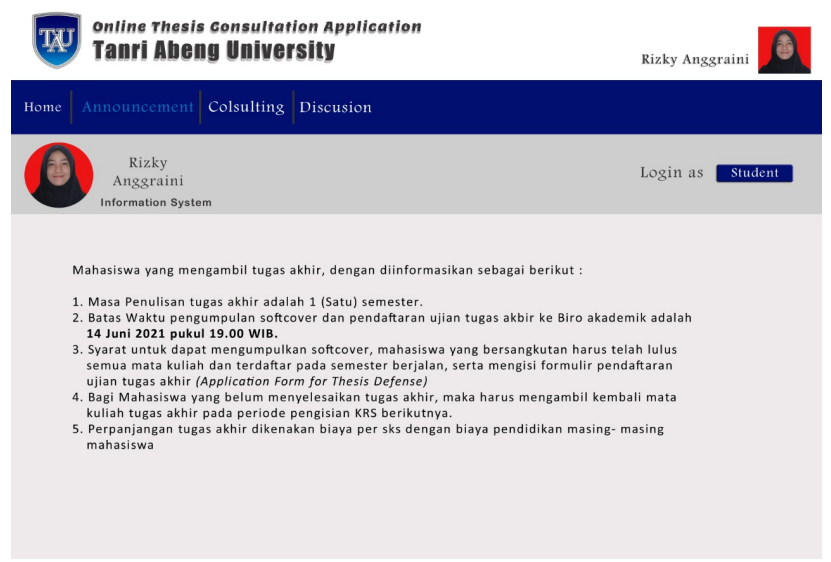

Gambar 6. Halaman announcements untuk mahasiswa

Halaman announcements berisi berita atau informasi untuk dosen pembimbing dan mahasiswa terkait timeline yang merupakan tanggal penting dan persyaratan penyelesaian skripsi.

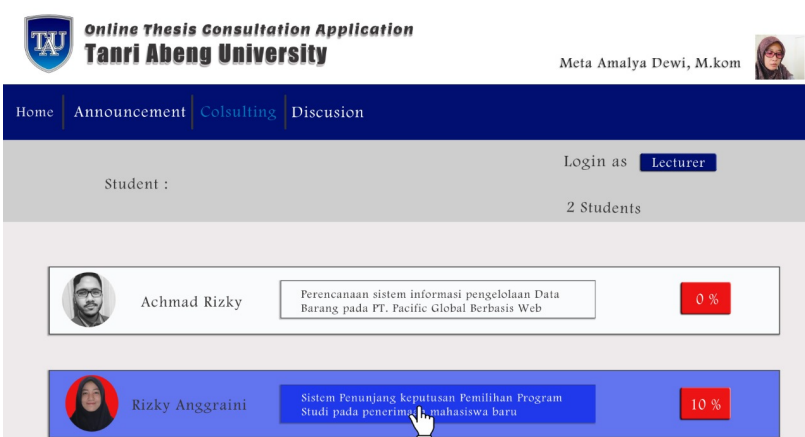

Gambar 7. Halaman consulting untuk dosen

Selanjutnya gambar 7 adalah halaman consulting dosen, terdapat nama mahasiswa bimbingan dengan judul skripsi dan progress penyelesaiannya, tampak mahasiswa pertama masih $0 \%$ karena belum ada berkas yang disubmit untuk diperiksa, sementara mahasiswa kedua sudah submit penulisan bab I dan diperiksa dosen. Langkah berikutnya dosen dapat klik pada nama mahasiswa atau judul skripsi untuk unduh berkas yang akan diperiksa.
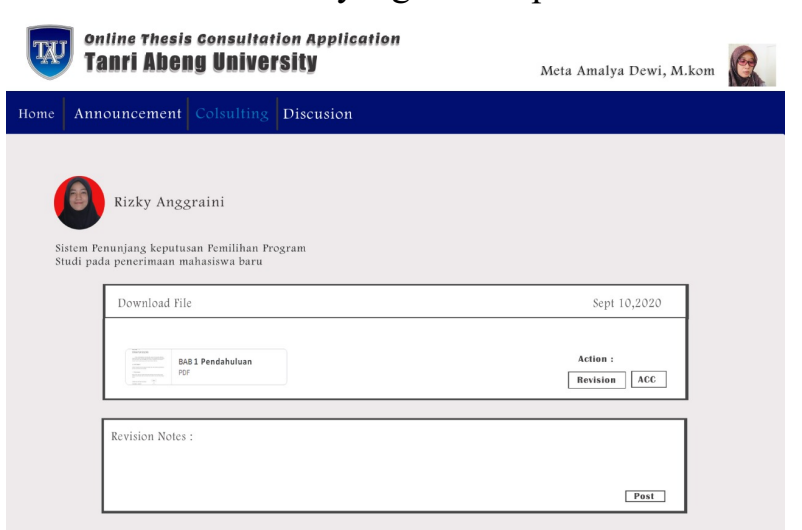

Gambar 8. Halaman unduh berkas

Pada gambar 8 di atas dosen dapat mengunduh berkas mahasiswa dan disampingnya ada tombol aksi revision yang jika diklik maka akan muncul revision notes sebagai tempat untuk membuat catatan perbaikan, juga ada tombol aksi ACC jika penulisan sudah sesuai. 


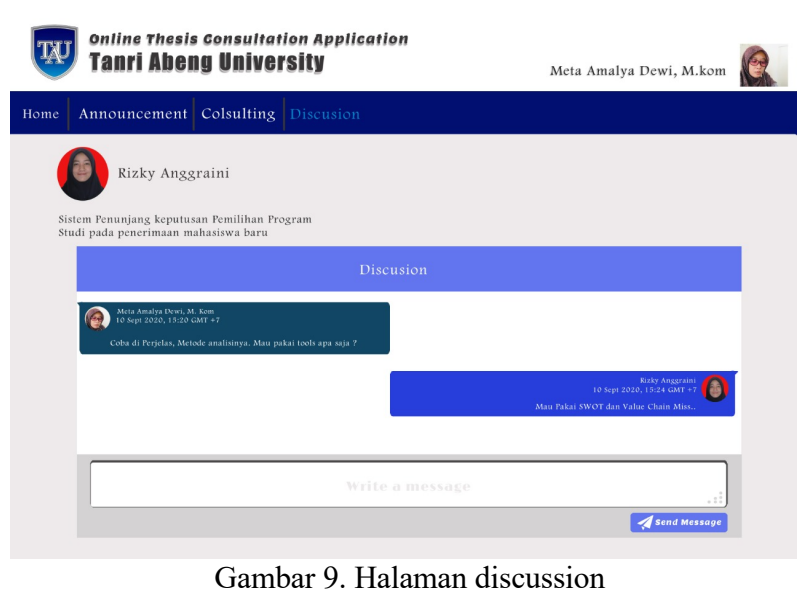

Gambar di atas menunjukkan halaman diskusi yang dapat dilakukan oleh mahasiswa dan dosen pembimbing secara interaktif.

\section{KESIMPULAN}

Pengembangan aplikasi bimbingan daring skripsi mahasiswa dengan metode scrum dilaksanakan dengan 4 sprint dimana setiap sprint dilaksanakan tidak lebih dari 30 hari kalender, yaitu sprint 1 hanya 73 jam, sprint 2 selama 103 jam, sprint 3 dan 4 masing-masing 80 jam sehingga total durasi yang dibutuhkan 336 jam atau 9 minggu dengan 8 jam perhari selama 5 hari.

Hasil rancangan yang dinamakan Online Consultation Thesis Application Tanri Abeng University (OCTA-TAU) sebagai solusi pelaksanaan pembimbingan skripsi secara daring selama pandemi yang tidak memungkinkan pertemuan secara langsung antara mahasiswa dengan dosen pembimbingnya dengan menyediakan catatan perbaikan secara digital dan monitoring capaian penyelesaian skripsi mahasiswa
DAFTAR PUSAKA

[1] Djarwanto. Petunjuk Teknis Penyusunan Skripsi. Yogyakarta: BPFE, 1992.

[2] Undang-Undang Republik Indonesia Nomor 12 Tahun 2012. Pendidikan Tinggi. 10 Agustus 2012. Lembaran Negara Republik Indonesia Tahun 2012 Nomor 158. Jakarta

[3] Program Studi Sistem Informasi. Pedoman Penyusunan Tugas Akhir, Universitas Tanri Abeng, 2018

[4] Rektor Tanri Abeng University. Surat Edaran Pencegahan dan Pengendalian Covid-19, Universitas Tanri Abeng, 2020.

[5] Menteri Pendidikan dan Kebudayaan. Surat Edaran Pencegahan dan Pengendalian Covid-19, 2020.

[6] M. Saleh. "Merdeka Belajar di Tengah Pandemi COVID-19". Prosiding Seminar Nasional Hardiknas, 2020, hal 51-56

[7] Niken Bayu Argaheni, "Sistematik Review: Dampak Perkuliahan Daring Saat Pandemi Covid-19 Terhadap Mahasiswa Indonesia". PLACENTUM Jurnal Ilmiah Kesehatan dan Aplikasinya, vol.8 (2) 2020

[8] A. Nugroho, Rekayasa Perangkat Lunak Menggunakan UML dan Java. Yogyakarta: Andi Offset, 2010, hal. 6.

[9] F. Mubarok, Harliana, dan I. Hadijah, "Perbandingan Antara Metode RUP dan Prototype Dalam Aplikasi Penerimaan Siswa Baru Berbasis Web", Citec Journal, vol. 2 No. 2, 2015, hal. 114-127.

[10] K. Made, "Implementasi Metodologi Scrum dalam Pembangunan Situs Harga Komoditas”, Jurnal Sistem Informasi, Vol. 9 No. 2, 2014, hal. 149-160.

[11] K. Schwaber. Scrum Development Process, in OOPSLA Business Object Design and Implementation Workshop. London: Springer, 1997.

[12] P. Kimmel, UML Demistified, Osborne: McGraw-Hill, 2005.

[13] N. Bhadoriya, N. Mishra, dan A. Malviya, "Agile Software Development Methods, Comparison with Traditional Methods \& Implementation in Software Firm", International Journal of Engineering Research and Technology, vol. 3, no. 7, 2014, hal. 1656-1662,

[14] S.R. Bharamagoudar, R.B. Geeta, S.G. Totad. Web Based Student Information Management System. IJARCCE. 2013

[15] T. Satpathy. Scrum Body Of Knowledge : Sbok Guid. 2016. 